\title{
EFFECT OF ENVIRONMENTAL DISTURBANCES ON ODONATA ASSEMBLAGES ALONG A TROPICAL POLLUTED RIVER
}

\author{
NURUL HUDA ABDUL ${ }^{1}$, CHE SALMAH MD RAWI' ${ }^{1}$, ABU HASSAN AHMAD ${ }^{1}$, SALMAN \\ ABDO AL-SHAMI ${ }^{*}$
}

${ }^{1}$ School of Biological Sciences, Universiti Sains Malaysia, 11800 Penang, Malaysia

${ }^{2}$ Department of Biology, University College of Taymma, University of Tabuk, Taymma, P. O. Box 741, Tabuk, Saudi Arabia; e-mail: salshami@ut.edu.sa, alshami200@gmail.com

* Author for correspondence

\begin{abstract}
Abdul N.H., Rawi Che S.Md., Ahmad A.H., Al-Shami S.A.: Effect of environmental disturbances on Odonata assemblages along a tropical polluted river. Ekológia (Bratislava), Vol. 36, No. 4, p. 388-402, 2017.

Odonata larvae have been intensively used as bioindicators for freshwater pollution as their community structure closely follow changes in the environment and habitat settings. In this study, 28 taxa of Odonata larvae were collected from three stations (upper, middle and lower) of a polluted river in Malaysia. The upper river basin receives effluents from an oil palm plantation. However, the middle station is presumably contaminated with anthropogenic wastes. The lower station is found to receive polluted discharges from aquaculture outlet. Several environmental parameters of water and sediment were continuously measured during the study. The water parameters showed no significant differences amongst the three stations. The species richness of Odonata was 22, 24 and 20 in the upper, middle and lower stations, respectively. The abundance of Odonata was significantly different among the studied sites. The tolerant damselfly, Pseudagrion sp. (41.22\%), and facultative dragonflies, Onychothemis sp. (17.12\%), were the most dominant taxa along the river stations. Onychothemis sp. and Paragomphus capricornis were equally important at the upper station [Important Species Index (ISI) 25.3 and 24.2\%, respectively]. Pseudagrion sp. only scored an ISI value of $9.7 \%$. Pseudagrion sp., P. capricornis and Onychothemis sp. were dominant in the middle station (ISI: $41.2 \%, 25.9 \%$ and $10.9 \%$ respectively), and Pseudagrion sp., Onychothemis sp. and Prodasineura sp. dominated the areas with dense growth of submerged aquatic weeds Hydrilla sp. in the lower station (ISI: $47.9,24.5$ and $13.8 \%$, respectively). On the basis of the variations in larval abundance and ISI values, microhabitats differences partly in response to different types of pollutions entering the water structured the Odonata communities in this river basin.
\end{abstract}

Key words: dragonfly, larval assemblage, pollution, distribution and abundance, tropical river.

\section{Introduction}

Aquatic macroinvertebrates are an important component of the food web in tropical aquatic ecosystem (Ridzuan et al., 2017). Both larvae and adults are predators of smaller macroin- 
vertebrates and some fingerlings, hence, are important component of the aquatic food chain. Although several orders of aquatic macroinvertebrates inhabit freshwater habitats, two insect orders, Odonata (dragonflies) and Heteroptera (bugs), comprise a large contribution to species richness of aquatic insects in the neotropics and tropics (Jacobsen et al., 2008). Although of little economic importance, dragonflies have considerable potential as indicator of environmental disturbance in either terrestrial or aquatic habitat (Corbet, 1999; Orr, 2004; Villalobos-Jimenez et al., 2016).

Odonata have wide distribution and interact with the environmental conditions because they inhabit the sediment and between rocks or leaves and are associated with macrophytes. Macroinvertebrates show different distribution patterns at different spatial and temporal scales (Al-Shami et al., 2013a,b) as well as at different physical and chemical settings (AlShami et al., 2011; Al-Shami et al., 2013a,b; Che Salmah et al., 2013; Al-Shami et al., 2014a; Che Salmah et al., 2014; Martin, Maynou, 2016). Odonata larvae depend on the characteristic of the aquatic habitat, and hence, they are sensitive to changes in the environmental settings. Therefore, they have been widely used as bioindicators for environmental health and integrity. In aquatic environments, habitat integrity is an important factor structuring the aquatic communities of insects including Odonata (Souza et al., 2015; Martin, Maynou, 2016). However, different aquatic insects including Odonata develop several physiological and morphological adaptations to encounter the deterioration in the habitat quality (for morphological adaptation, see Al-Shami et al., 2014b).

Environmental factors such as light, water flow, type of substratum and width and depth of water bodies cause different species of dragonflies to form the communities (Corbet, 1999). Other important factors are liability to drought and flood, food, competition between inter and intra species, shade and quite importantly the zoogeography. The distribution of Odonata in streams is highly dependent on the particle sizes of the substrate, nature of organic detritus and food availability under different condition (Scheffer et al., 1984; Che Salmah et al., 2005). In addition, the stream ecosystem is highly influenced by the riparian vegetation, which contributes allochthonous organic matter that forms a large part of the food base (Hynes, 1970; Mitsch, Gosselink, 2000; Wantzen et al., 2008). According to Souza et al. (2015), diversity and distribution of Odonata larvae are generally influenced by alteration in the habitat structure. This increases their potential to be applied as indicators for environmental pollution in the aquatic ecosystems (Berquier et al., 2016).

In this study, communities of Odonata living in differently polluted habitats were investigated to understand the impact of pollution loads on their diversity and abundance. Specifically, the aspects that can indicate alterations such as (i) individual species abundance, (ii) species richness; (iii) species abundance in relation to the Odonata assemblages, (iv) physical integrity of the stream banks and (v) physicochemical water parameters were measured in this study. Although most of the dragonfly species are widespread in polluted and moderately polluted waters, the finding of this study would elucidate the importance of pollution loads and river parameters in regulating the assemblages of Odonata communities in a disturbed river. Species preferring extreme ranges of water parameters would serve as good bioindicators for such river. This biological assessment of water quality would contribute to better understanding of the role of aquatic organisms in the aquatic ecosystems and enhance the 


\section{conventional approach of chemical water quality monitoring for sustainable management of water resource in the future.}

\section{Material and methods}

\section{Study site}

This study was carried out in a relatively small Serdang River, one of the tributaries of Kerian River basin bordering Kedah and Perak States in the northern Malaysian Peninsula. Three sampling stations were selected based on different human activities in the surrounding areas and source of pollution discharging into the river (Fig. 1). Water current was relatively fast in all stations. Station 1 is an upper section of the river, which was relatively small (river width ranged from 4 to $5 \mathrm{~m}$ ), passing through an oil palm plantation. The substrate in this station is sandy, and the water depth was $0.1-0.5 \mathrm{~m}$. Water surface was covered (shaded) with dense canopies of oil palm trees, planted along the stream banks. The river banks were made up of oil palm roots and, in some parts, covered with weeds. Main source of pollutant load came from dissipation of agriculture inputs such as fertiliser, insecticides and herbicides applied regularly to maintain good growth and production of oil palm trees. In station 2, approximately $4 \mathrm{~km}$ downstream from station 1, the substrate of the river was sandy and mixed with alluvial soil in some parts. This portion of the river passed through urban and residential areas collecting mainly anthropogenic wastes from both places. The water was shallow and river width ranged from 11 to $12.5 \mathrm{~m}$ with a depth of $0.1-0.7 \mathrm{~m}$. The water level occasionally increased to $1.5 \mathrm{~m}$ during rainy season. Semi-aquatic weeds grew densely on both sides of the banks and water surface was completely exposed to sunlight. About $1.6 \mathrm{~km}$ downwards was station 3 . This part of the river received discharge from an aquaculture pond. Both sides of the river banks were covered by semi-aquatic weeds and the substrates supported a dense growth of submerged Hydrilla sp. River size and type of substrate were almost similar to station 2 but the water surface was partly shaded with oil palm leaves from trees planted on one side of the river bank.

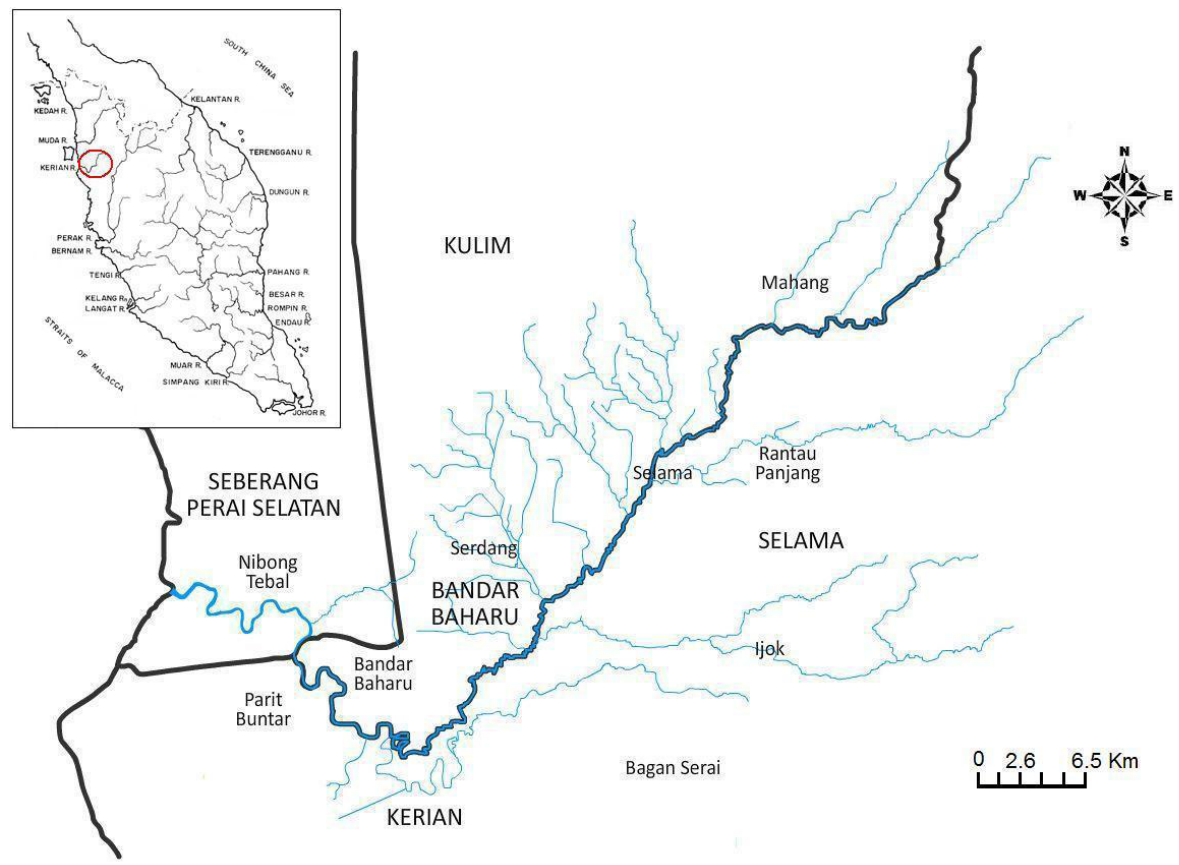

Fig. 1. Map of the approximate study sites in Serdang River, Kerian River basin, Malaysia. 
Odonata larvae were collected from July 2008 to August 2009 using a D-pond aquatic net with $40 \times 30 \mathrm{~cm}$ frame, $50-\mathrm{cm}$ long net of about $30-\mu \mathrm{m}$ mesh equipped with a handle of about $1.5 \mathrm{~m}$ long. Ten samples were collected from each station monthly. A sample consisted of a meter ${ }^{2}$ drag of aquatic net over river substrates or marginal vegetation (Ghani et al., 2016). The samples were sorted in the laboratory and all specimens were preserved in $75 \%$ alcohol. The specimens were identified following the taxonomical keys of Yule and Yong (2004), Dudgeon (1999), Morse et al. (1994), Orr (2005) and Fonseka (2000).

\section{Measurement of physicochemical parameters and biotic integrity analysis}

Selected water and river physicochemical parameters such as $\mathrm{pH}$, dissolved oxygen (DO), water temperature and river width and depth were measured in situ using appropriate metres. The amount of shading and water flow was recorded qualitatively for all sampling stations. Water samples were transferred to the laboratory for analysis of BOD (biochemical oxygen demand), TSS (total suspended solid) and water turbidity. Analyses of the physical characteristic of the sites were carried out according to the Habitat Physical Integrity Score (HPIS) that includes characteristics of the riparian forest, river banks and channel structure presumably related to human disturbances. The score is calculated as the sum of all the element values considered for the assessment (Daniel de paiva Silva et al., 2010, and modified from Nessimian et al., 2008). The resulted score is inversely related to the physical integrity of the sites.

\section{Statistical analyses}

In all statistical tests, a 95\% confidence limit was applied except for the correlation coefficients (Pearson r) in which 99 and 95\% confident limits were considered. Composition, abundance and homogeneity of species per unit area in all sampling stations were represented by Simpson's Index of Diversity (1-D), Menhinick's Richness Index $\left(R_{2}\right)$ and Simpson's Reciprocal or Evenness Index $(E=1 / D)$. Difference in distribution of mean abundances of odonate taxa amongst all sampling stations was calculated using the Kruskal-Wallis test suitable for non-normally distributed data. Species abundance pattern were determined by fitting the data to the log series distribution and evaluated using the standard test of Chi-square goodness of fit. The log series distribution is described by the following equation (Fisher et al., 1943; Magurran, 2004):

$$
\mathrm{S} / \mathrm{N}=[(1-\mathrm{x}) / \mathrm{x}] \cdot[-\ln (1-\mathrm{x})]
$$

where $\mathrm{N}$ is the total number of individuals,

$$
\mathrm{S}=\alpha \ln (1+\mathrm{N} / \alpha)
$$

where $\alpha$ is an index diversity. As $\mathrm{x}$ often approximates to $1, \alpha$ represents the number of extremely rare species where only a single individual is expected:

$$
\alpha=(\mathrm{N}(1-\mathrm{x})) / \mathrm{x} \text {. }
$$

\section{Results}

Diverse dragonfly communities were reported from three sampling stations in Serdang River. A total of 5,655 individuals were collected, which were assigned to 8 families and 28 taxa. The zygopteran taxa Pseudagrion sp. was the most abundant (41.22\%) and collected in high numbers from all stations. The second species that was predominant in station 1 was Onychothemis sp. (17.12\%). Other taxa made up less than $10 \%$ of total individuals in all stations. All sampling stations accommodated similar odonate families, but the highest number of individuals and taxa (24) were recorded at station 2. Fewer individuals were collected from 
station 1 compared to other stations (1131); however, they represented 22 odonate taxa. In station 3, 20 taxa were identified from 2,086 individuals sampled there. Varied number of taxa and individuals recorded in the three stations were at least partly attributed to the variations in river characteristics and pollution loads encountered in each station (Hawking, New, 1999; Norma-Rashid et al., 2001). On the basis of the Kruskal-Wallis test, there was a significant difference in the total abundance of dragonflies community at all sampling stations $\left(\chi^{2}\right.$ $=31.594, \mathrm{df}=2, \mathrm{p}<0.05)$.

The distribution and abundance of odonates in Serdang River are presented by using the ISI, which was calculated from relative density and frequency occurrences of the taxa in each station (Table 1). Paragomphus capricornis and Onychothemis sp. have higher ISI

$\mathrm{T}$ a b l e 1. Important Species Index (ISI) values recorded in all stations represented by taxa.

\begin{tabular}{|l|c|c|c|}
\hline Taxa & Upper station & Middle station & Lower station \\
\hline Macrogomphus & 0.006 & 0.006 & \\
\hline P. capricornis & 24.217 & 25.893 & 2.422 \\
\hline B. williamsoni & 6.042 & 3.059 & 2.333 \\
\hline B. divaricatus & 0.401 & 0.095 & 0.012 \\
\hline Orientogomphus & 0.111 & 0.02 & \\
\hline Megalogomphus & 0.022 & & \\
\hline G. perakensis & 0.065 & 0.017 & 0.015 \\
\hline Libellago & 5.036 & 8.911 & 6.896 \\
\hline Rhinocypha & & & 0.032 \\
\hline Pseudagrion & 9.698 & 41.156 & 47.819 \\
\hline Ischnura & & 0.086 & 0.022 \\
\hline Agriocnemis & 0.022 & 0.094 & 0.066 \\
\hline Ceriagrion & 0.014 & 0.003 & \\
\hline Aciagrion & & 0.007 & \\
\hline Onychothemis & 25.644 & 10.938 & 24.497 \\
\hline Trithemis & 2.274 & 4.003 & 2.327 \\
\hline Diplacodes & 0.005 & 0.085 & 0.009 \\
\hline Nannophyla & 0.011 & 0.003 & \\
\hline Brachythemis & & & 0.006 \\
\hline Orthetrum & 0.114 & 1.32 & 0.563 \\
\hline Neurothemis & 0.009 & 0.021 & \\
\hline Crocothemis & & 0.003 & \\
\hline Copera & 0.207 & 2.314 & 0.527 \\
\hline Platycnemis & & 0.003 & 0.002 \\
\hline Macromia & 8.944 & 5.92 & 2.932 \\
\hline Idionyx & 0.074 & & 0.002 \\
\hline Vestalis & 1.402 & 1.241 & \\
\hline Neurobasis & 0.455 & 0.066 & \\
\hline Prodasineura & 1.351 & & \\
\hline
\end{tabular}
scores in station 1 compared to two other taxa. In station 2, Pseudagrion sp. had the highest ISI values followed by $P$. capricornis, whilst in station 3 , Pseudagrion sp. also occurred in high abundance and, hence, high ISI scores followed by Onychothemis sp. Taxa that were only collected from single station during this study were Megalogomphus (station 1), Aciagrion and Crocothemis (station 2) and Rhinocypha and Brachythemis (station 3).

Odonates taxa were grouped into three main clusters using the hierarchical clustering analysis based on the similarities amongst clusters (Fig. 2). Pseudagrion (166.500 \pm 35.660 , mean \pm standard error respectively), Onychothemis (69.143 \pm 10.869$)$ and P. capricornis (37.786 \pm 6.720$)$ were grouped into one cluster (dominant), indicating tolerant taxa with high abundance in polluted water (Lieftinck, 1954; Orr, 2005; Ngiam, 2009). Prodasineura (5.500 \pm 1.108), Copera (6.929 \pm 1.679$)$, Orthetrum (12.786 \pm 8.244), 


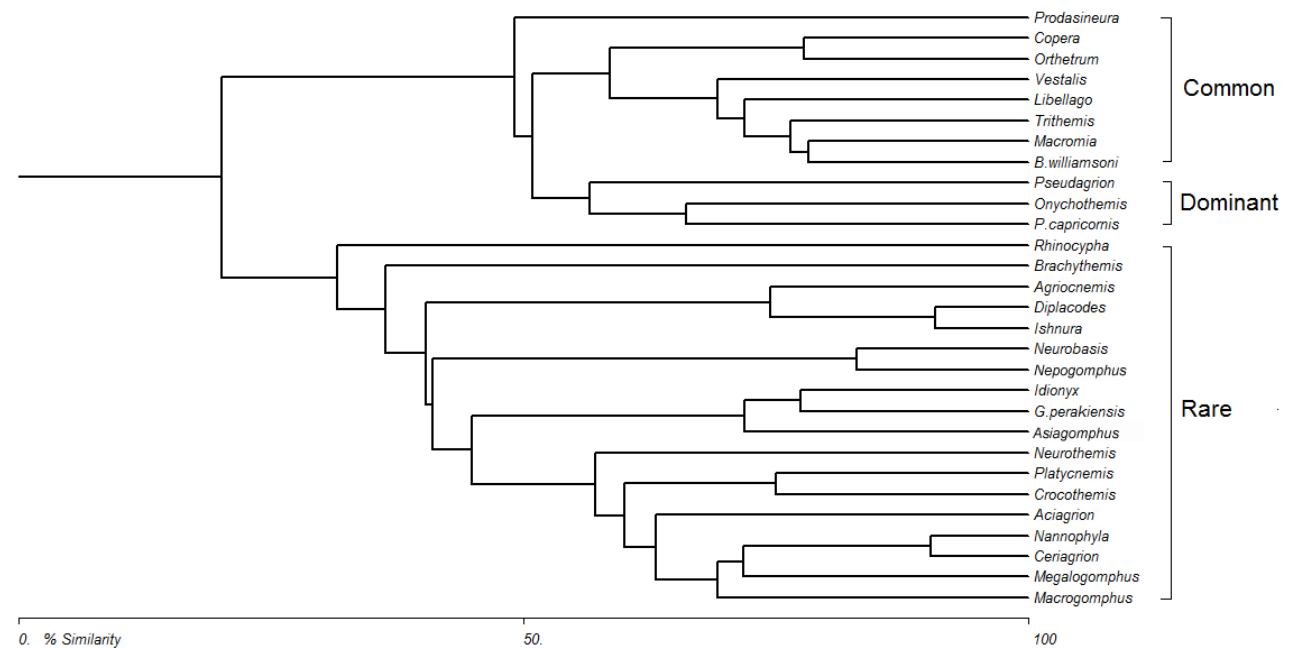

Fig. 2. A dendrogram of Bray-Curtis cluster analysis showing similarities amongst Odonata taxa in Serdang River based on their abundance.

Vestalis (6.214 \pm 0.984), Libellago (37.500 \pm 9.131), Trithemis (17.071 \pm 4.680$)$, Macromia (19.500 \pm 2.563$)$ and Burmagomphus williamsoni (14.429 \pm 3.326$)$ were classified as common taxa representing a less-tolerant group (Orr, 2003, 2005; Lok, 2008). Other taxa with fewer individuals made up a slightly sensitive or rare group because their densities were very low in all stations (Orr, 2005; Norma-Rashid et al., 2008). These groupings showed that the diversities and abundances of odonate taxa corresponded to the ISI scores calculated for each species, which is given in Table 1.

Variations in total abundance and composition of odonates were observed at different stations in the Serdang River. Station 1 recorded the highest scores of all indices (Simpson's $1-\mathrm{D}=0.83$, Simpson's $1 / \mathrm{D}=0.255, \mathrm{R}_{2}=0.624$ ) followed by station 2 (Simpson's $1-\mathrm{D}=0.771$, Simpson's $1 / \mathrm{D}=0.174$ and $\mathrm{R}_{2}=0.506$ ). The lowest scores of diversity, richness and evenness indices were calculated in station 3, although higher number of individuals were collected from this site (Simpson's $1-\mathrm{D}=0.648, \mathrm{R}_{2}=0.460$, Simpson's $1 / \mathrm{D}=0.135$ ) than those in station 2. Variations in composition and abundance of Odonata in Serdang River may reflect the presence of differential environmental stress at each station, as fewer disturbances were observed in station 1 compared to stations 2 and 3.

The species-abundance distribution of odonates in all sampling stations in Serdang River fitted to the log series model (Fig. 3). Species ranks are plotted in sequence from the most to the least abundant along $\mathrm{x}$-axis. The slope of the curves determined the degree of disturbance in each station. Table 2 summarised the species-abundance relationship of Odonata that were fitted into a log series model. The higher value of $\chi^{2}$ at station 3 indicates higher degree of disturbance at this station compared with other stations, fitted better to log series model. 


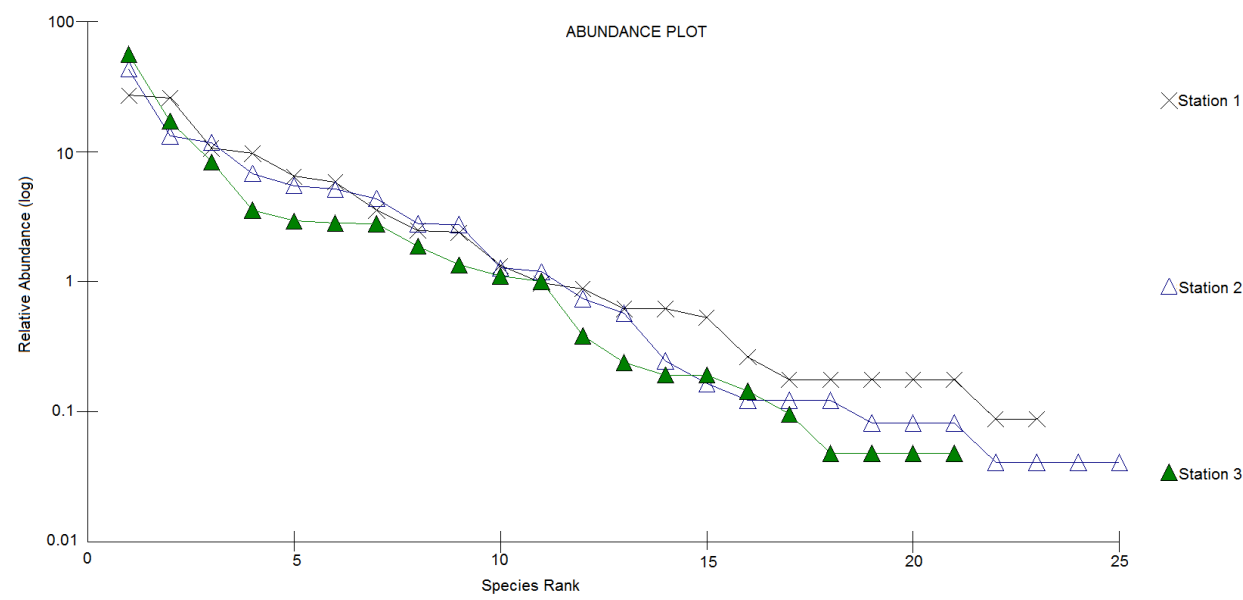

Fig. 3. Species-abundance relationship of all stations in Serdang River.

$\mathrm{T}$ a b 1 e 2. Species-abundance distribution pattern observed for odonates in Serdang River using standard Chisquare goodness of fit test.

\begin{tabular}{|l|c|c|c|c|c|}
\hline Station & $\boldsymbol{\chi}^{\mathbf{2}}$ & $\mathbf{d f}$ & $\mathbf{p}$ & $\mathbf{\alpha}$ & $\mathbf{x}$ \\
\hline Station 1 & 0.319 & 3 & 0.956 & 4.091 & 0.996 \\
\hline Station 2 & 0.640 & 4 & 0.958 & 3.881 & 0.998 \\
\hline Station 3 & 1.126 & 4 & 0.890 & 3.250 & 0.998 \\
\hline
\end{tabular}

$\mathrm{T}$ a b l e 3. Mean \pm standard error of river physicochemical parameter and scores of biotic integrity of three stations in Serdang River.

\begin{tabular}{|l|c|c|c|}
\hline River characteristics & Upper station & Middle station & Lower station \\
\hline Depth $(\mathrm{m})$ & $0.10-0.50$ & $0.10-1.5$ & $0.10-1.5$ \\
\hline Width $(\mathrm{m})$ & $4-5$ & $11-12.5$ & $11-12.5$ \\
\hline Dissolved oxygen $(\mathrm{mg} / \mathrm{L})$ & $6.92 \pm 0.292$ & $6.98 \pm 0.219$ & $6.49 \pm 0.210$ \\
\hline $\mathrm{pH}$ & $5.92 \pm 0.103$ & $6.01 \pm 0.097$ & $5.99 \pm 0.072$ \\
\hline Water temperature $\left({ }^{\circ} \mathrm{C}\right)$ & $25.60 \pm 0.497$ & $26.29 \pm 0.736$ & $26.00 \pm 0.620$ \\
\hline Total suspended solid (mg/L) & $11.14 \pm 1.249$ & $30.36 \pm 10.041$ & $33.77 \pm 11.325$ \\
\hline Turbidity (NTU) & $7.06 \pm 1.203$ & $20.74 \pm 6.570$ & $28.58 \pm 14.270$ \\
\hline Biochemical oxygen demand (mg/L) & $1.36 \pm 0.217$ & $1.86 \pm 0.294$ & $1.18 \pm 0.150$ \\
\hline Habitat Physical Integrity Score (HPIS) & 39 & 37 & 37 \\
\hline
\end{tabular}

Temporal variations in water parameters at all stations in Serdang River were statistically different according to the Chi-square values of the Kruskal-Wallis test at $\mathrm{p}<0.05$ (DO: $\chi^{2}=$ 26.486, BOD: $\chi^{2}=38.768$, turbidity: $\chi^{2}=31.709$ and TSS: $\left.\chi^{2}=77.815\right)$ except for the $\mathrm{pH}$ and water temperature. Table 3 summarised the physicochemical parameter of water quality at 
each station. DO and BOD were much lower in station 3 compared to other stations. The water was more turbid with high content of suspended solid in stations 2 and 3 . These two stations also shared similar HPIS (37). High scores of HPIS at all stations indicated that their riparian forests, river banks and structures have been modified or disturbed by human activities. Nevertheless, station 1 that had relatively better water quality with higher DO content and lower TSS and water turbidity than other stations scored higher HPIS (range of scores 12-55) mainly because it was located in an oil palm plantation that categorised it into a very disturbed land use category.

Table 4 shows the influence of physicochemical parameters on the abundances of odonate taxa in Serdang River. Most of the water parameters did not or very weakly influence odonate abundances as most $r$ values were less than $\pm 0.300(\mathrm{p}=0.05)$. However, water temperature showed positive correlation with several taxa. In general, within the ranges recorded in the river, the abundances of odonate larvae in all stations were not affected by physicochemical parameters of the water.

T a b l e 4. Correlation coefficients (Pearson r) values of Odonata taxa as influenced by selected water parameters.

\begin{tabular}{|l|c|c|c|c|c|c|}
\hline Taxa & $\mathbf{p H}$ & $\mathbf{D O}$ & $\begin{array}{c}\text { Water } \\
\text { Temperature }\end{array}$ & Turbidity & TSS & BOD \\
\hline P. capricornis & 0.084 & $\mathbf{0 . 0 9 9 ^ { \mathbf { b } }}$ & $\mathbf{0 . 1 1 5}^{\mathbf{b}}$ & $-\mathbf{0 . 0 9 8}^{\mathbf{b}}$ & -0.049 & -0.010 \\
\hline B. williamsoni & 0.052 & $\mathbf{0 . 1 3 2}^{\mathbf{a}}$ & 0.042 & $-\mathbf{0 . 1 2 4}^{\mathbf{b}}$ & $-\mathbf{0 . 1 2 4}^{\mathbf{b}}$ & -0.068 \\
\hline B. divaricatus & $\mathbf{0 . 1 2 0}^{\mathbf{b}}$ & -0.031 & -0.050 & -0.054 & -0.051 & -0.035 \\
\hline Libellago & 0.085 & 0.084 & 0.034 & $-\mathbf{0 . 1 4 0}^{\mathbf{a}}$ & $-\mathbf{0 . 1 7 6}^{\mathbf{a}}$ & -0.032 \\
\hline Pseudagrion & $\mathbf{0 . 0 9 8}^{\mathbf{b}}$ & $-\mathbf{0 . 1 6 3}^{\mathbf{a}}$ & $\mathbf{0 . 2 6 3}^{\mathbf{a}}$ & -0.027 & -0.050 & 0.025 \\
\hline Agriocnemis & -0.010 & -0.016 & $\mathbf{0 . 1 3 4}^{\mathbf{a}}$ & -0.072 & -0.063 & -0.041 \\
\hline Ceriagrion & 0.006 & $-\mathbf{0 . 1 0 4}^{\mathbf{b}}$ & $\mathbf{0 . 1 9 5}^{\mathbf{a}}$ & -0.018 & -0.024 & $\mathbf{0 . 1 1 1}^{\mathbf{b}}$ \\
\hline Onychothemis & 0.078 & 0.038 & -0.024 & $-\mathbf{0 . 1 1 2}^{\mathbf{b}}$ & $-\mathbf{0 . 1 0 8}^{\mathbf{b}}$ & $-\mathbf{0 . 1 3 3}^{\mathbf{a}}$ \\
\hline Trithemis & 0.051 & -0.039 & $\mathbf{0 . 2 9 1}^{\mathbf{a}}$ & $-\mathbf{0 . 1 1 6}^{\mathbf{b}}$ & $-\mathbf{0 . 1 0 3}^{\mathbf{b}}$ & -0.064 \\
\hline Orthetrum & 0.052 & -0.036 & $\mathbf{0 . 1 9 5}^{\mathbf{a}}$ & -0.084 & -0.090 & 0.002 \\
\hline Copera & 0.065 & -0.017 & $\mathbf{0 . 3 0 0}^{\mathbf{a}}$ & -0.074 & -0.049 & 0.039 \\
\hline Platycnemis & 0.051 & $-\mathbf{0 . 1 0 8}^{\mathbf{b}}$ & $\mathbf{0 . 2 0 7}^{\mathbf{a}}$ & -0.009 & -0.003 & 0.033 \\
\hline Macromia & 0.031 & $\mathbf{0 . 1 6 1}^{\mathbf{a}}$ & 0.022 & -0.094 & -0.076 & -0.068 \\
\hline Idionyx & 0.073 & $-\mathbf{0 . 1 2 0}^{\mathbf{b}}$ & $\mathbf{0 . 1 3 5}^{\mathbf{a}}$ & -0.030 & -0.037 & 0.079 \\
\hline Prodasineura & 0.065 & $\mathbf{0 . 1 0 8}^{\mathbf{b}}$ & 0.039 & $-\mathbf{0 . 0 9 6}^{\mathbf{b}}$ & -0.086 & 0.018 \\
\hline
\end{tabular}

Notes: ${ }^{\text {a }}$ Correlation is significant at the 0.01 level; ${ }^{\mathrm{b}}$ Correlation is significant at the 0.05 level.

\section{Discussion}

The distribution and abundance of aquatic insects such as Odonata in aquatic habitat is very much dependent on their sensitivity to pollution or habitat alteration (Scheffer et al., 1984; Vinson, Hawkins, 1998; Che Salmah et al., 2005; Subramaniam, Sivaramakrishnan, 2005; Milesi et al., 2009) especially to a condition that may affect the $\mathrm{pH}$, DO content, water temperature, turbidity and other water parameter (Ward, Stanford, 1982; Wallace, Anderson, 
1996; Connolly et al., 2004; Smith, Lamp, 2008; Walters et al., 2009). In this study, there was no marked difference in diversity of Odonata distributed along different stretches of Serdang River. However, their abundances differed substantially amongst stations. More individuals were collected in stations 2 and 3 that received anthropogenic waste and aquaculture discharge, respectively, and fewer numbers were collected from station 1 that was situated in an oil palm plantation with only chemical runoff contaminating the water.

Oil palm industry is one of the major incomes for economic development in Malaysia since its first commercial planting in 1917. The expansion of oil palm plantation causes forest degradation and loss of biodiversity (Abdullah, Nakagoshi, 2008; Iwata et al., 2003; Che Salmah et al., 2013) especially in wetland areas (Wantzen et al., 2008; Verhoeven, Setter, 2010). According to Hershey, Lamberti (1998), increased sedimentation and runoff as a consequence of land clearing decreased detritus input, which resulted in low insect diversity in rivers passing through human-modified riparian land use type. This statement partially explained the lower odonate diversity (22 taxa) recorded in station 1, although the score of Simpson's Diversity Index at this station was higher than the remaining stations. The oil palm trees were almost 20 years old, but during this study, the river received sediments continuously because the river substratum was completely covered with coarse and fine sand and the water depth was low. This kind of substrates in clear running water is preferred by some gomphids (Kalnins, 2006) such as Megalogomphus (only found at this station); hence, more gomphid taxa of relatively higher abundances were recorded at this station.

The use of chemicals (pesticides and fertilizers) in agricultural lands may affect the water quality of the surrounding water bodies. After herbicide applications, plant death and decay change the water chemistry and oxygen levels and cause loss of habitats, breeding sites and food supply (Mason, 1981). Macrophytes, semi-aquatic plants and non-target organisms such as sensitive dragonflies disappear when lethal concentration is sufficient to cause direct mortality. Sublethal effect includes changing in behaviour and physiological activity of the macroinvertebrates such as reproduction, maturation and morphological changes or deformities (Simpson, Roger, 1995; Al-Shami et al., 2010).

Usually pesticides were excessively used in oil palm plantations to increase fruit harvests. Leachates of regularly used pesticides (and fertilizers) in this plantation flowed into the river when it rained. Evidently, at station 1, only few grasses and sparsely scattered shrubs were left around the study area. Facultative anisopteran such as Onychothemis sp. was more adaptive in station 1, clinging on roots of oil palm trees at or around the banks. The zygopterans prefer semiaquatic weeds for resting or as refuges. Disappearance of these habitats reduced the populations of Zygoptera at this station. Furthermore, the water surface was completely shaded by dense canopy of Elaeis guineensis, limiting the penetration of the light into the water. Low input of light decreases primary production in the water, which subsequently decreases the benthic secondary productions (Davies et al., 2008, Che Salmah et al., 2012). Most of the taxa collected at this station were those of shade-loving Odonata.

Stations 2 and 3 shared almost similar river physical characteristics, although the water quality differed substantially at times because of different pollution loading at both stations. Their water was sometimes yellowish and murky with unpleasant smells. Sediment loads and anthropogenic effect from aquaculture activities and urbanisation polluted the water 
considerably, causing more habitat disturbance that restricted the distribution of some dragonfly taxa. However, facultative and tolerant dragonflies preferred these two stations possibly because of food availability and suitability of microhabitats provided by semi-aquatic weed and submerged plant along the river margins. Microhabitat with many types of vegetation support higher diversity and distribution of Odonata (Wazhizatul-Afzan et al., 2006; Hornung, Rice, 2003).

In station 2, marginal and riparian vegetations that consist of mixed grasses, sparse growth of pioneer trees and shrubs appear to significantly reduce the effect of deforestation caused by expansion of urbanisation on odonates community (Lorion, Kennedy, 2009). The marginal plants specifically provided suitable perching and mating sites for the dragonflies that lead to larger population at this station. Adult Odonata are visually oriented hunters with extremely acute eyesight. Many are strong fliers, and most of them prefer open and half-shaded area. According to Kalkman et al. (2008), open landscapes are generally better for tropical species to colonise new habitats and these dragonflies seem to be less influenced by habitat modification. They can recolonise impacted areas in the presence of good growth of riparian vegetations. As station 2 met this habitat quality, more individuals from various taxa were collected from this station.

Enriched water from urbanisation waste also provided food source for primary prey of odonates, Chironomus sp. (Diptera: Chironomidae) and nutrients for the weeds. Decomposition of organic matters, for example, fallen leaves and also food waste from residential areas increased soft sediments, which was favourable to this dipteran (Hawtin, 1998). In the presence of dense growth of weeds, the population of dragonfly especially tolerant genus Pseudagrion surged at this station. In addition, allochthonous detritus from the riparian area provide important source of food and habitat for macroinvertebrates (Allan, 1995; Polis et al., 1997), including dragonflies, which contributes to increased diversity of invertebrates in the ecosystem.

Discharge from aquaculture project adversely affected the diversity of intolerant aquatic macroinvertebrates through increased nutrient and solid loads (Viadero et al., 2005; Buzby et al., 2007). In contrary, higher concentration of basic nutrients enables huge growth of moss, algae and a specific community of macroinvertebrates (Helesic et al., 1998). More tolerant taxa (mainly zygopterans) inhabited station 3. Anisopterans such as libellulids and cordulids were equally distributed in this station compared to other stations but lesser gomphids were collected. Poor substrates of sandy and muddy bottom, which comprised of alluvial soil and pollutants, made it unsuitable for sand dwelling gomphids. In addition, excessive nutrients resulted in healthy growth of submerged Hydrilla sp. that covered substantial areas of the substrate surface and supported high diversity and abundance of climbing and crawling dragonflies such as libellulids and coenagrionids. According to Savino, Stein (1982), Schramm et al. (1987) and Colon-Gaud et al. (2004), macroinvertebrates densities including Odonata would be higher in area covered by Hydrilla because of higher stem and canopy densities that provide ample refuges from fish predation. On the other hand, enriched water, such as observed at this station, lead to high TSS content and high water turbidity, limiting light penetration (Davies et al., 2008) and photosynthetic activity of primary producers (Lewis, 2008). Low primary production can only support low number of secondary consum- 
ers such as dragonflies. In Table 2, negative impact of turbidity was evident for six odonate taxa in station 3.

Shading by riparian canopy cover can significantly suppress or reduce primary production in streams (Spanhoff, 2005). Early studies suggest that many odonate species avoided shaded areas because shaded vegetation produces variation of microclimates and reduces habitat selection of Trithemis (Libellulidae) adults (Remsburg et al., 2008). In Serdang river, Aciagrion and Crocothemis seemed to display similar behaviour as observed in Trithemis (Remsburg et al., 2008) and chose to perch in wide open area with short vegetation in station 2. Furthermore, open areas encourage an extreme proliferation of algal growth and increased water temperature. Higher temperatures can force earlier emergence of aquatic insect larvae by accelerating their development (Vannote, Sweeney, 1980) and thus result in high population abundance. In contrast, in this study, larvae of Onychothemis displayed a preference for shaded area because many larvae were collected from completely or partially shaded habitats especially in station 3. In station 2, Onychothemis was collected in very low abundance.

Besides the influence of environmental variations on each station, differences in diversity, abundance and distribution of larval odonates along Serdang River could be influenced by a prey-predator relationship. Aquatic macroinvertebrates are important food source for stream fishes, and insects are common in diet of many fishes next to small crustaceans (Winemiller et al., 2008). Pierce et al. (1985) showed that Enallagma (Coenagrionidae) population was reduced in the presence of bluegills fish. In the Serdang River, station 1 was presumably free of fish because this part of the river was narrow and the water was shallow, unsuitable for fish. The distributions of dragonfly larvae in station 1 were most likely regulated by the water quality and river physical characteristic as well as food and habitat availability. Some fishes such as omnivorous catfish and Tilapia sp. could inhabit station 3. However, these fish are herbivores during most part of their lives. Very few fish was observed in station 2.

The abundance of odonate larvae in Serdang River fitted the log series model. The fit to this model is interpreted as a result of domination of certain taxa on resource availability in that area. Steep plots of rank/abundance plot signify assemblages with high dominance of limited taxa approaching geometric and log series distribution (Magurran, 2004), which allows the comparison of different animal assemblages between study areas (Fisher et al., 1943). The a value of the log series distribution model represents the number of extremely rare species such as only single individual is expected. In station 3, higher proportions of resources were monopolised by Pseudagrion because almost half of the odonates population was contributed by this genus. The lowest $\alpha$ value calculated for the dragonfly community at this station implied low numbers of rare species expected in station 3 with the consequence of lower species richness. Similar distribution pattern can also be seen in station 2 because of the dominance of Pseudagrion but less steep curve in station 1 indicated that resources were better distributed amongst more than 1 dominant species (e.g. P. capricornis and Onychothemis). The result from Death (1996) also supports this finding that disturbed and unstable sites would have less equitable species abundance distributions, strongly dominated by one or two species and would be modelled best by geometric or log series distribution model. The log series distribution model also indicated that the population of Odonata in this environment would diminish once the resources available reach quantities lower than the minimum 
required for maintaining the population (Daniel de paiva Silva et al., 2010). This type of distribution usually reflects the area with slightly polluted to moderately polluted river.

\section{Conclusion}

As a summary, the assemblages of dragonflies in various stations along Serdang River were not directly influenced by the pollution discharged into each station but were more regulated by the changes in microhabitats that subsequently influenced the structures of the community in each station. Habitat preferences of some taxa were clearly observable, hence, predicting the community assemblages in relation to the types of pollution received in the river.

\section{Acknowledgements}

We are indebted to the Dean of School of Biological Sciences, Universiti Sains Malaysia, for providing laboratory facilities and transportation to the study sites. We are grateful to Dr. Rodolfo Novelo Guteirrez of Intituto Ecologia, Xalapa, Mexico for verifying the identification of larval dragonflies. Our warm appreciation goes to Adibah Mohd Isadi, Mohd Shafiq Zakeyuddin and Wan Hafezul Wan Abdul Ghani for tireless help in the field. This research was funded by the Research University Grant no 1001/PBIOLOGI/850716.

\section{References}

Abdullah, S.A. \& Nakagoshi N. (2008). Landscape ecological approach in oil palm land use planning and management for forest conservation in Malaysia. In S.K. Hong, N. Nakagoshi, B. Fu \& Y. Morimoto (Eds.), Landscape ecological application in man-influenced areas: Linking man and nature systems (pp. 179-191). Netherland: Springer Publisher. DOI: 10.1007/1-4020-5488-2.

Allan, D.J. (1995). Stream ecology: Structure and function of running waters. London: Chapman \& Hall.

Al-Shami, S., Rawi, C.S.M., Siti Azizah, M.N., Ahmad, A.H. \& Ali A. (2010). Morphological deformities in Chironomus spp. (Diptera: Chironomidae) larvae as a tool for impact assessment of anthropogenic and environmental stresses on three rivers in the Juru river system, Penang, Malaysia. Environ. Entomol., 39(1), 210-222. DOI: 10.1603/EN09109.

Al-Shami, S.A., Rawi, C.S.M., Ahmad, A.H., Hamid, S.A. \& Nor S.A.M. (2011). Influence of agricultural, industrial, and anthropogenic stresses on the distribution and diversity of macroinvertebrates in Juru river basin, Penang, Malaysia. Ecotoxicol. Environ. Saf., 74(5), 1195-1202. DOI: 10.1016/j.ecoenv.2011.02.022.

Al-Shami, S.A., Heino, J., Rawi, C.S.M., Ahmad, A.H., Suhaila, A.H. \& Madrus M.R. (2013a). Drivers of beta diversity of macroinvertebrate communities in tropical forest streams. Freshw. Biol., 58(6), 1126-1137. DOI: 10.1111/fwb.12113.

Al-Shami, S.A., Rawi, C.S.M., Ahmad, A.H. \& Madrus M.R. (2013b). Biodiversity of stream insects in the Malaysian Peninsula: spatial patterns and environmental constraints. Ecol. Entomol., 38(3), 238-249. DOI: 10.1111/ een.12013.

Al-Shami, S.A., Hishamuddin, S.N., Rawi, C.S.M., Abdul, N.R. \& Ahmad A.H. (2014a). Developmental instability in Odonata larvae in relation to water quality of Serdang river, Kedah, Malaysia. Life Science Journal, 11(7), 152-159. DOI: 10.7537/marslsj110714.19.

Al-Shami, S.A., Rawi, C.S.M., Ahmad, A.H., Madrus, M.R. \& Mutairi K.A. (2014b). Importance of regional diversity and environmental conditions on local species richness of aquatic macro-invertebrates in tropical forested streams. J. Trop. Ecol., 30(04), 335-346. DOI: 10.1017/S0266467414000200.

Berquier, C., Orsini, A., Ferrat, L. \& Andrei-Ruiz M.-C. (2016). “Odonata Community Index-Corsica”(OCIC): A new biological index based on adult odonate populations for assessment of the ecological status of watercourses in Corsica. Ecological Indicators, 66, 163-172. DOI: 10.1016/j.ecolind.2016.01.022.

Buzby, K.M. \& Viadero R.C. Jr. (2007). Structural and functional aspects of treated mine water and aquaculture effluent streams. Hydrobiologia, 583, 251-263. DOI: 10.1007/s10750-006-0534-0.

Che Salmah, M.R., Abu Hassan, A. \& Wazhizatul-Afzan A. (2005). Preliminary study on the composition and distribution of Odonata in Perlis State Park. Malay. Nat. J., 57(3), 317-326. 
Che Salmah, M.R., Al-Shami, S.A., Md Shah, A.S.R., Ahmad, A.H. \& Man A. (2012). Effects of herbicides on Odonata communities in a rice agroecosystem. Toxicological \& Environmental Chemistry, 94(6), 1188-1198. DOI:1 $0.1080 / 02772248.2012 .689837$.

Che Salmah, M.R,, Al-Shami, S.A., Madrus, M.R. \& Ahmad A.H. (2013). Local effects of forest fragmentation on diversity of aquatic insects in tropical forest streams: implications for biological conservation. Aquat. Ecol., 47(1), 75-85. DOI: 10.1007/s10452-012-9426-8.

Che Salmah, M.R., Al-Shami, S.A., Madrus, M.R. \& Ahmad A.H. (2014). Biological and ecological diversity of aquatic macroinvertebrates in response to hydrological and physicochemical parameters in tropical forest streams of Gunung Tebu, Malaysia: implications for ecohydrological assessment. Ecohydrology, 7(2), 496-507. DOI: $10.1002 /$ eco. 1368 .

Colon-Gaud, J.C., Kelso, W.E. \& Rutherford D.A. (2004). Spatial distribution of macroinvertebrates inhabiting $H y$ drilla and Coontail beds in the Atchafalaya Basin, Louisiana. J. Aquat. Plant Manag., 42, 85-91.

Connolly, N.M., Crossland, M.R. \& Pearson R.G. (2004). Effect of low dissolved oxygen on survival, emergence, and drift of tropical streams macroinvertebrates. Journal of North American Benthological Society, 23(2), 251-270. http://www.jstor.org/stable/10.1899/0887-3593(2004)023<0251:eoldoo>2.0.co;2

Corbet, P.S. (1999). Dragonflies: behavior and ecology of Odonata. Cornell University Press.

Daniel de paiva Silva, de Marco, P. \& Resende D.C. (2010). Adult odonate abundance and community assemblage measures as indicators of stream ecological integrity: A case study. Ecological Indicators, 10, 744-752. DOI: 10.1016/j.ecolind.2009.12.004.

Davies, P.M., Bunn, S.E. \& Hamilton S.K. (2008). Primary production in tropical streams and rivers. In D. Dudgeon (Ed.), Tropical stream ecology (pp. 23-42). USA: Elsevier.

Death, R.G. (1996). The effect of habitat stability on benthic invertebrate communities utility of species abundance distributions. Hydrobiologia, 317, 97-107. DOI: 10.1007/BF00018733.

Dudgeon, D. (1999). Tropical Asian streams: Zoobenthos, ecology and conservation. Hong Kong: Hong Kong University Press.

Fisher, R.A., Corbet, A.S. \& Williams C.B. (1943). The relation between the number of species and the number of individuals in a random sample of an animal population. J. Anim. Ecol., 12, 42-58. DOI: 10.2307/1411.

Fonseka, T. (2000). The dragonflies of Sri Lanka. Sri Lanka: WHT Publication (Private) Limited.

Ghani, W.M.H.W.A., Rawi, C.S.M., Hamid, S.A. \& Al-Shami S.A. (2016). Efficiency of different sampling tools for aquatic macroinvertebrate collections in Malaysian streams. Tropical Life Sciences Research, 27(1), 115.

Hawking, J.H. \& New T.R. (1999). The distributions patterns of dragonflies (Insecta: Odonata) along the Kiewa river, Australia and their relevance in conservation assessment. Hydrobiologia, 392, 249-260. DOI: 10.1023/A:1003510514937.

Hawtin, E. (1998). Chironomid communities in relation to physical habitat. In G. Bretschko \& J. Helesic (Eds.), Advances in river bottom ecology (pp. 175-184). Leiden: Backhuys Publishers.

Helesic, J., Kubicek, F. \& Zahradkova S. (1998). The impact of regulated flow and altered temperature regime on river bed macroinvertebrates. In G. Bretschko \& J. Helesic (Eds.), Advances in river bottom ecology (pp. 225-243). Leiden: Backhuys Publishers.

Hershey, A.E. \& Lamberti G.A. (1998). Stream macroinvertebrate communities. In R.J. Naiman \& R.E. Bilby (Eds.), River ecology and management - Lesson from the Pacific coastal ecoregion (pp. 169-199). New York: SpringerVerlag.

Hornung, J.P. \& Rice C.L. (2003). Odonata and wetland quality in Southern Alberta Canada: A preliminary study. Odonatologica, 32(2), 119-129. http://natuurtijdschriften.nl/record/592431

Hynes, H.B.N. (1970). The ecology of running water. Toronto: Toronto Press.

Iwata, T., Nakano, S. \& Inoue M. (2003). Impact of past riparian deforestation on streams communities in a tropical rain forest in Borneo. Ecol. Appl., 13(2), 461-473. DOI: 10.1890/1051-0761(2003)013[0461:IOPRDO]2.0.CO;2.

Jacobsen, D., Cressa, C., Mathooko, J.M. \& Dudgeon D. (2008). Macroinvertebrates: Composition, life histories and production. In D. Dudgeon (Ed.), Tropical stream ecology (pp. 65-105). USA: Elsevier.

Kalkman, V.J., Clausnitzer, V., Dijkstra, K.D.B., Orr, A.G., Paulson, D.R. \& Jan van Tol (2008). Global diversity of dragonflies (Odonata) in freshwater. Hydrobiologia, 595, 351-363. DOI: 10.1007/s10750-007-9029-x.

Kalniņs, M. (2006). The distribution and occurrence frequency of Gomphidae (Odonata: Gomphidae) in river Gauja. Acta Universitatis Latviensis, Biology, 710, 17-28.

Lewis, W.M.Jr. (2008). Physical and chemical features of tropical flowing waters. In D. Dudgeon, (Ed.), Tropical stream ecology (pp. 1-21). USA: Elsevier. 
Lieftinck, M.A. (1954). Handlist of Malaysian Odonata. Treubia, 22(Suppl.), 51-150. DOI: DOI: 10.14203/treubia. v22i0.2682.

Lok, A.F.S.L. (2008). The biology and distribution in Singapore of Prodasineura humeralis Selys, 1860. Nature in Singapore, 1, 51-53.

Lorion, C.M. \& Kennedy B.P. (2009). Relationships between deforestation, riparian forest buffers and benthic macroinvertebrates in neotropical headwater streams. Freshw. Biol., 54(1), 165-180. DOI: 10.1111/j.13652427.2008.02092.x.

Magurran, A.E. (2004). Measuring biological diversity. Oxford: Blackwell Science Ltd.

Martín, R. \& Maynou X. (2016). Dragonflies (Insecta: Odonata) as indicators of habitat quality in Mediterranean streams and rivers in the province of Barcelona (Catalonia, Iberian Peninsula). International Journal of Odonatology, 19, 107-124. DOI: $10.1080 / 13887890.2016 .1172991$.

Mason, C.F. (1981). Biology of freshwater pollution. New York: Longman Inc.

Milesi, S.V., Biasi, C., Restello, R.M. \& Hepp L.U. (2009). Distribution of benthic macroinvertebrates in Subtropical streams (Rio Grande do Sul, Brazil). Acta Limnologica Brasiliensia, 21(4), 419-429.

Mitsch, W.J. \& Gosselink J.G. (2000). Wetlands. New York: John Wiley \& Sons Inc.

Morse, J.C., Liangfang, Y. \& Tian L. (Eds.) (1994). Aquatic insects of China useful for monitoring water quality. Nanjing: Hohai University Press.

Nessimian, J.L., Venticinque, E., Zuanon, J., De Marco, P., Gordo, M., Fidelis, L., Batista, J.D. \& Juen L. (2008). Land use, habitat integrity and aquatic insect assemblages in Central Amazonian streams. Hydrobiologia, 614, 117-131. DOI: 10.1007/s10750-008-9441-x.

Ngiam, R.W.J. (2009). The biology and distribution of Pseudagrion rubriceps rubriceps Selys, 1876 (Odonata: Zygoptera: Coenagrionidae) in Singapore. Nature in Singapore, 2, 209-214.

Norma-Rashid, Y., Mohd-Sofian, A. \& Zakaria-Ismail M. (2001). Diversity and distribution of Odonata (dragonflies and damselflies) in the fresh water swamp lake, Tasek Bera, Malaysia. Hydrobiologia, 459, 135-146. DOI: 10.1023/A:1012562611307.

Norma-Rashid, Y., Cheong, L.F., Lua, H.K. \& Murphy D.H. (2008). The Dragonflies (Odonata) of Singapore: Current Status Records and Collections of the Raffles Museum of Biodiversity Research. Raffles Museum of Biodiversity Research National University of Singapore.

Orr, A.G. (2003). A guide to the dragonflies of Borneo: their identification and biology. Natural History Publications (Borneo) Kota Kinabalu, Sabah, Malaysia.

Orr, A.G. (2004). Critical species of Odonata in Malaysia, Indonesia, Singapore and Brunei. International Journal of Odonatology, 7, 371-384. DOI: 10.1080/13887890.2004.9748222.

Orr, A.G. (2005). A pocket guide: Dragonflies of Peninsular Malaysia and Singapore. Natural History Publications (Borneo) Kota Kinabalu, Sabah, Malaysia.

Pierce, C.L., Crowley, P.H. \& Johnson D.M. (1985). Behavior and ecological interactions of larval odonata. Ecology, 66(5), 1504-1512. DOI: $10.2307 / 1938013$.

Polis, G.A., Anderson, W.B. \& Holt R.D. (1997). Toward and integration of landscape and food web ecology: the dynamics of spatially subsidized food webs. Annu. Rev. Ecol. Evol. Syst., 28, 289-316. DOI: 10.1146/annurev. ecolsys.28.1.289.

Remsburg, A.J., Olson, A.C. \& Samways M.J. (2008). Shade alone reduces adult dragonfly (Odonata: Libellulidae) abundance. J. Insect Behav., 21, 460-468. DOI: 10.1007/s10905-008-9138-z.

Ridzuan, D.S., Che Salmah, M.R., Suhaila, A. \& Al-Shami S.A. (2017). Determination of food sources and trophic position in Malaysian tropical highland streams using carbon and nitrogen stable isotopes. Acta Ecological Sinica, 37(2), 97-104. DOI: 10.1016/j.chnaes.2016.10.002.

Savino, J.F. \& Stein R.A. (1982). Predator-prey interaction between largemouth bass and bluegills as influenced by simulated, submersed vegetation. Trans. Am. Fish. Soc., 111, 255-266. DOI: 10.1577/1548-8659(1982)111<255:PIBLBA $>2.0 . \mathrm{CO} ; 2$.

Scheffer, M., Achterberg A.A. \& Beltman S. (1984). Distribution of macroinvertebrates in a ditch in relation to the vegetation. Freshw. Biol., 14, 367-370. DOI: 10.1111/j.1365-2427.1984.tb00160.x.

Schramm, H.L. Jr., Jirka, K.J. \& Hoyer M.V. (1987). Epiphytic macroinvertebrates on dominant macrophytes in two central Florida lakes. J. Freshw. Ecol., 4, 151-161. DOI:10.1080/02705060.1987.9664649

Simpson, I.C. \& Roger P.A. (1995). The impact of pesticides on non-target aquatic invertebrates in wetland rice fields: a review. In P.L. Pingali \& P.A. Roger (Eds.), Impact of pesticides and farmer health and the rice environment (pp. 249-270). Los Banos: IRRI Editions. 
Smith, R.F. \& Lamp W.O. (2008). Comparison of insect communities between adjacent headwater and main-stem streams in urban and rural watersheds. Journal of North American Benthological Society, 27(1), 161-175. DOI: 10.1899/07-071.1.

Souza, A., Fogaça, F., Cunico, A. \& Higuti J. (2015). Does the habitat structure control the distribution and diversity of the Odonatofauna? Braz. J. Biol., 75(3), 598-606. DOI: 10.1590/1519-6984.18213.

Spänhoff, B. (2005). Effect of permanent shading on adult size and biomass of the caddisfly Lype phaeopa (Stephens, 1836) (Psychomyiidae). Hydrobiologia, 549, 179-186. DOI: 10.1007/s10750-005-1299-6

Subramanian, K.A. \& Sivaramakrishnan K.G. (2005). Habitat and microhabitat distribution of stream insect communities of the Western Ghats. Curr. Sci., 89(6), 976-987.

Vannote, R.L. \& Sweeney B.W. (1980). Geographic analysis of thermal equilibria: A conceptual model for evaluating the effect of natural and modified thermal regimes of aquatic insect communities. Am. Nat., 115(5), 667-695.

Verhoeven, J.T.A. \& Setter T.L. (2010). Agricultural use of wetlands: opportunities and limitations. Ann. Bot., 105(1), 155-163. DOI: 10.1093/aob/mcp172.

Viadero, R.C. Jr., Cunningham, J.H., Semmens, K.J. \& Tierney A.E. (2005). Effluent and production impacts of flowthrough aquaculture operations in West Virginia. Aquac. Eng., 33, 258-270. DOI: 10.1016/j.aquaeng.2005.02.004.

Villalobos-Jimenez, G., Dunn, A. \& Hassall C. (2016). Dragonflies and damselflies (Odonata) in urban ecosystems: A review. Eur. J. Entomol., 113, 217-232. DOI: 10.14411/eje.2016.027.

Vinson, M.R. \& Hawkins C.P. (1998). Biodiversity of stream insects: Variation at local, basin and regional scales. Annu. Rev. Entomol., 43, 271-293. DOI: 10.1146/annurev.ento.43.1.271.

Wallace, J.B. \& Anderson N.H. (1996). Habitat, life history and behavioral adaptations of aquatic insects. In R.W. Merritt \& K.W. Cummins (Eds.), An introduction to the aquatic insects of North America (pp. 41-73). Dubuque: Kendall/Hunt Publishing Company.

Walters, D.M., Roy, A.H. \& Leigh D.S. (2009). Environmental indicators of macroinvertebrate and fish assemblages integrity in urbanizing watersheds. Ecological Indicators, 9, 1222-1233. DOI: 10.1016/j.ecolind.2009.02.011.

Wantzen, K.M., Yule, C.M., Tockner, K. \& Junk W.J. (2008). Riparian wetlands of tropical streams. In D. Dudgeon (Ed.), Tropical stream ecology (pp. 199-217). USA: Elsevier. Ward, J.V. \& Stanford J.A. (1982). Thermal responses in the evolutionary ecology of aquatic insects. Annu. Rev. Entomol., 27, 97-117. DOI: 10.1146/annurev. en.27.010182.000525.

Wazhizatul-Afzan, A., Julia, J. \& Amirrudin A. (2006). Diversity and distribution of dragonflies (Insecta: Odonata) in Sekayu recreational forest, Terengganu. Journal of Sustainability Science and Management, 1(2), 97-106.

Winemiller, K.O., Agostinho, A.A. \& Caramaschi E.P. (2008). Fish ecology in tropical streams. In D. Dudgeon (Ed.), Tropical stream ecology (pp. 107-146). USA: Elsevier.

Yule, C.M. \& Yong H.S. (2004). Freshwater invertebrates of the Malaysian region. Academy of Sciences Malaysia. 